\title{
Influence of Head Teachers' Motivational Practices on Teacher Performance in Public Secondary Schools of Chililabombwe District- Zambia
}

\author{
Mawala Muluka Mukumbi*, Rachel Mabuku Kabeta \\ Zambia
}

*Corresponding Author: Mawala Muluka Mukumbi, Zambia

\begin{abstract}
This paper discusses the Influence of Head teachers' motivational practices on teacher Performance in Public Secondary Schools in Chililabobwe District of the Copperbelt Province in Zambia. The study adopted a mixed method design which included both qualitative and quantitative research methods. Data collection involved both closed and open-ended questionnaires and interviews. Random Sampling was used to select the teachers while the head teachers were selected by using purposive sampling. The respondents were asked whether the head teachers' motivational practices had influence on teachers' job performance; $76 \%$ of the participants agreed that it had because motivated teachers were easy to supervise and that such teachers performed their jobs very well thereby attracting more learners into the school. $84 \%$ of the respondents affirmed that local incentives provided by the head teacher improved teacher performance. The findings of the study revealed challenges faced by head teachers in trying to motivate teachers in public Secondary Schools, such as inadequate funding from government, non-payment of tuition fees by learners due to economic hardships, low staffing levels in some subjects and interference from political offices. The study concluded that head teachers play a vital role in motivating teachers and that these motivation practices had a positive impact on teachers' performance. The study recommends stronger and timely motivation practices by head teachers in order to enhance teacher performance. These practices may not necessarily be in monetary terms but such as commendation and appreciation of good performance by teachers.
\end{abstract}

Keywords: Head teacher, Motivational Practices, Teacher Performance, Public Secondary Schools

\section{INTRODUCTION}

Teacher motivation is a subject that has received significant attention in mainstream educational debate in recent decades. It has become an important aspect of teacher efficacy and professionalism given the teachers' responsibility of imparting knowledge and skills to learners. On one level teacher motivation is related to a long list of variables including whether or not an enabling environment exits and whether or not teachers are equipped to conduct their responsibilities effectively. Davidson (2004) noted that however at the basic level teacher motivation is linked to how teachers feel they are being treated and to the way they perceive their own working and living conditions.

It is said that a motivated teacher is a productive teacher, any kind of grievance relating to the school or personal to a greater extent has influence on the teaching job. Frase (1992) agreed that a motivated teacher is one who not only feels satisfied with his or her job but is empowered to strive for excellence and growth in instructional practice. If teachers are not motivated in their course of delivery, they do not take long in classroom activities that benefit learners instead take other jobs alongside teaching as a fulfillment of their frustration. Armstrong (2006) postulates that the head teacher, as a chief executive officer, needs to appreciate and recognize that good results are obtained through the people.

\subsection{Statement of the Problem}

The government of the Republic of Zambia is committed to the provision of quality education. It has continued to make efforts to motivate teachers by offering salary increments, sponsoring teachers for further studies among others. However, in spite of these government efforts to motivate teachers, learner performance in most of the public secondary schools has remained below the required 
provincial target of $80 \%$ which seems to point to poor teacher performance due to lack of motivation. As a result a number of schools have resorted to using different motivational practices to try and influence teachers to improve their performance. This study therefore endeavored to examine the influence of head teachers' motivational practices on teachers' job performance in public secondary schools in Chililabombwe district.

\subsection{Purpose}

The purpose of this study was to investigate the influence of head teachers' motivational practices on teacher performance in public secondary schools in Chililabombwe district of the Copper belt Province in Zambia.

\subsection{Research Objectives}

- To investigate the influence of head teachers' motivational practices on teachers job performance

- To find out the motivational practices used by head teachers to improve teachers job performance

\subsection{Research Questions}

- What influence do head teachers' motivational practices have on teachers' job performance?

- What motivational practices are used by head teachers to improve teachers' job performance

\subsection{Theoretical Framework}

\subsubsection{The Study was Guided by Frederick Herzberg's Theory of Motivation}

In 1959, Frederick Herzberg, a behavioral scientist proposed a two-factor theory or the motivatorhygiene theory. According to Herzberg, there are some job factors that result in satisfaction while there are other job factors that prevent dissatisfaction. According to Herzberg, the opposite of "Satisfaction" is "No satisfaction" and the opposite of "Dissatisfaction" is "No Dissatisfaction".

\subsubsection{Motivational Factors}

According to Herzberg, the motivational factors yield positive satisfaction and they are inherent to work. These factors motivate the employees for a superior performance. The factors in question are called satisfiers. The motivational factors are involved in performing the job. Employees find these factors intrinsically rewarding. The motivators symbolized the psychological needs that were perceived as an additional benefit. Motivational factors include: recognition, sense of achievement, Growth and promotional opportunities, responsibility and meaningfulness of work.

\subsection{Conceptual Framework}
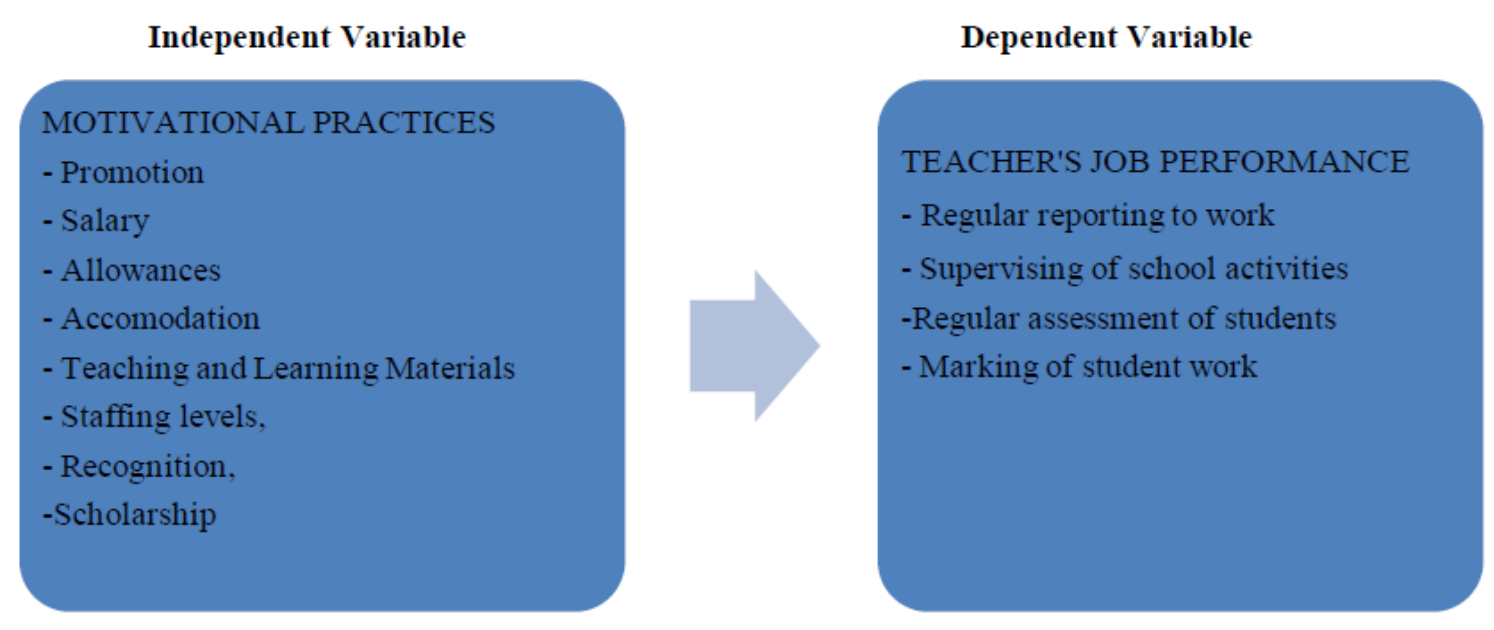

Source: Adopted from Nairuba Justine (2011) with slight modifications by author

\subsection{Significance of the Study}

The findings of this study may help to inform the policy makers, head teachers and teachers about the need by head teachers to motivate teachers beyond what government does. The findings may further 
provide insights into what needs to be done to improve teacher performance which in turn will impact on learner performance. It is also hoped that the study contributes to the body of knowledge regarding teacher motivation and performance.

\section{LITERATURE REVIEW}

\subsection{The Concept of Motivation}

Motivation is a feeling of happiness or contentment which takes place in people depending on circumstances on the job. It is the motivation and drive within a teacher that lead to effective delivery of teaching. Vroom (1964) rightly noted that a good motivated and committed teacher dedicates all his effort on his job. That is to say, he would prepare, teach and assess students' work on time and take his responsibility as his top most priority.

Similarly, Kyambalesa, (2000) observed that managers and administrators cannot effectively attain meaningful performances, unless they have the ability to induce their staff to fully invest their full energies, time and commitment at the workplace. Maicibi and Nkata, (2005) therefore were right to postulate that administrators in these institutions should always monitor and ensure that employees are motivated appropriately especially in those jobs and areas that contribute most to institutions.

Armstrong (2006) postulates that the head teacher, as a chief executive officer, needs to appreciate and recognize that good results are obtained through the people. Motivating workers is the work managers perform to inspire, encourage and compel people to take action. To motivate the employees, the employee must be reached, to reach him there must be a complete understanding of the complexity of his make-up. Motivation efforts must be directed towards improving organization operations. To be effective, however they must also be designed to show benefits to the employee. In fact, motivation can best be accomplished when workers are able to merge their personal ambitions with those of the organization.

Globally, motivation is a culturally bound practice with its roots from the industrial revolution in the European and American States, like Japan, Greece, Mexico, Denmark, Norway, Sweden and Netherlands where social needs were recognized as a basis for good performance and workers benefits were more sensitive to equality hence, equal treatment of workers (Robbins, 2003).

Belle (2007) conducted a study on the role of secondary school principals in motivating teachers in Mauritius. An empirical investigation based on qualitative research was conducted on two themes: motivational factors pertaining to the school based personal and professional needs of the teacher. Belle's (2007) study found that teachers were proud to work in attractive surroundings with wellmaintained facilities and impressive infrastructure. Collaboration, communication and collective problem solving generated a sense of professionalism, mutual care and support amongst the teachers. He further stated that teachers were motivated by the Head Teacher who was personal oriented and who practiced democratic leadership styles. Autocratic and purely task oriented Head Teacher approaches demotivate teachers.

Enumerating factors influencing teachers' productivity in public institutions in Nigeria, Emenike (2010) observed that; working conditions, availability of working tools and resources, improved Knowledge and skills through regular training, accessibility to information and a sense of recognition, superior remuneration and handsome reward system, are the critical ingredients of worker job performance. Teachers who are not provided with teaching and learning materials might always find excuses for their poor performance Aikaman and Interhalter (2005). Aikamam and Interhalter also pointed out that poor examination results were related to the teaching resources allocated to the teachers.

\section{MethodologY}

\subsection{Research Design}

In this study both quantitative and qualitative were used. The mixed method approach was used because it allowed the researcher to get more information on the topic. 


\subsection{Research Sample}

The study had a total of 100 respondents from the district. These were four (4) head teachers, 4 deputy head teachers, thirty two (32) heads of departments from all the four schools and sixty (60) teachers making a total of hundred (100). Simple random sampling was used to select the 64 teachers while the head teachers and heads of departments were picked using purposive sampling.

\subsection{Research Instruments, Data Collection Procedures and Data Analysis}

The instruments that were used for data collection are questionnaires and interviews. In this study, data was also collected through interviews in a face-to-face interaction between the interviewer and the interviewees by using structured interview schedule. The quantitative data was analyzed using Microsoft excel where numbers were assigned to response categories and the qualitative data was analyzed thematically.

\subsection{Ethical Considerations}

Ethical considerations were taken into account such as seeking permission from relevant authorities from the Ministry of Education and Provincial Education Offices and taking into consideration issues of respondent's confidentiality and other basic research conventions.

\section{FINDINGS AND DISCUSSION}

\subsection{Influence of Head Teachers' Motivational Practices on Teachers' Job Performance}

The study established that motivational practices had positive influence as it motivated the teacher to work harder resulting into improved performance.

The influence of head teachers' motivational practices on teachers' job performance were perceived as follows:

Head teacher A said "motivation hikes the performance percentage rate and attracts learners into school".

Head teacher D stressed that depending on the type of motivation, the performance is enhanced.

Teacher 1 said it motivational practices makes the teachers to work freely and happy.

Teacher 2 said it makes them work very hard.

Teacher 3 noted that a motivated teacher performs well without being pushed.

Teacher 4 stressed that if teachers are motivated they perform better.

The findings suit with Vroom (1964) who noted that a good motivated and committed teacher dedicates all his effort on his job. It must be noted here that the human resources component in educational management and administration is an important factor which should be properly harnessed for effective and successful running of educational institutions (Bauleni, 2005).Frase (1992) agreed that a motivated teacher is one who not only feels satisfied with his or her job but is empowered to strive for excellence and growth in instructional practice. If teachers are not motivated in their course of delivery, they do not take long in classroom activities that benefit learners instead take other jobs alongside teaching as a fulfillment of their frustration. Armstrong (2006) postulates that the head teacher, as a chief executive officer, needs to appreciate and recognize that good results are obtained through the people.

\subsection{Motivational Practices}

This study also sought to establish motivational practices used by head teachers to improve teachers' job performance. According to the study, 26 (26\%) participants cited providing learning and teaching materials, $32(32 \%)$ cited awarding teachers on Teacher's Day and labour Day, 12 (12\%) cited formation of committees in a school and $30(30 \%)$ cited the use of period loss track registers as ways to motivate teachers.

Motivation practices in this study, were monetary (salary, wages, and other financial resources offered to teachers) they might also include free or subsidized housing, food and transport. And nonmonetary (fringe benefits and nature of working conditions) they might include professional status in 
the community, promotion, recognition, approval by parents, the general public and ministry of education. Motivational practices were measured by using Four Likert scales: $1=$ strongly disagree, $2=$ agree, $3=$ disagree, and $4=$ strongly agree.

Performance in this study, performance can be measured almost by any behavior, which is directed toward task or goal accomplishment, the job responsibilities or duties performed by the teacher. It includes professional status in the community, promotion, recognition and approval by, parents, the general public and Ministry of Education.

It was discovered that at one school, the head teacher uses period loss track registers as ways to motivate teachers as well as to check on which teachers attend to their classes and which ones miss. Teachers said period registers enabled school management to deal with culprits straight away at the end of each week without beating about the bush. In so doing, culprit teachers improved because the period loss reports were filed by Head teacher, H.O.Ds and individual teachers weekly. Educating Our Future (1996; p159) states that "Excellence is not something that happens in a school, it is something that must be deliberately and painstakingly created and maintained. Instructional leaders are viewed as culture builders. Teachers said the culture created at this school was to do away with teacher period loss, and it is an open secret as all stake holders were involved from head teacher, teachers to learners. A period loss track register is a tool designed to monitor teaching and learning. At the end of the week the head teacher gives each H.O.D a report on which class was not attended to. The periods lost in a week accumulate to months and make-up the periods lost by one teacher per year. The teachers with zero period loss are awarded and those found wanting are dealt with.

Teachers who are not provided with teaching and learning materials might always find excuses for their poor performance (Aikaman and Interhalter 2005). Aikamam and Interhalter further also pointed out that poor examination results were related to the teaching resources allocated to the teachers. Johari (2014) agrees with Mutono(2010) on whathe revealed in his study which investigated the role of school leadership in motivating teachers. His study showed that non availability of teaching and learning materials negatively affected teacher motivation. He further stated that it was the school leadership's responsibility to provide the teaching and learning materials to the teachers. Therefore, head teachers should strive to provide all the learning and teaching materials required for effective teaching. Educating Our Future (1996; p159) states that "Excellence is not something that happens in a school, it is something that must be deliberately and painstakingly created and maintained. Instructional leaders are viewed as culture builders. They sought to create an 'academic press' that fosters high expectations and standards for students, as well as for teachers (Mortimore, 1993; Purkey \& Smith, 1984).

The majority of participants (32\%) supported awarding teachers on Teacher's Day and labour Day. The study findings are consistent with affirmations by Cappelli, et.al (2001) who noted that incentive programs motivate employees to push and challenge themselves to achieve higher degrees of productivity. Cappelli, et.al (2001) observed that incentives come in different ways, including giving awards on Labour Day or teacher's Day. However, the school administrators should be careful when giving awards to teachers because some awards can demotivate other teachers. Adam's Equity theory demonstrates that the individuals are concerned both with their own rewards and also with what others get in comparison. Employees expect a fair and equitable return for their contribution to their jobs.

The researcher observed that Teacher's Day and Labour Day awards were so important to teachers and must be handled with care from selection of awardees to giving of the prize itself. Bass \& Riggio (2006) showed strong and consistent findings that conclude that transformational leaders have more satisfied followers than non-transformational leaders. Leaders who are inspirational show commitment to a vision or cause in the organization and challenge their followers to input and think, showing real concern for them can create satisfaction among the follower. In other words, leaders who contingently reward his or her followers would have more satisfied followers.

\subsection{Motivating Factors/Strategies}

The study investigated how best head teachers can motivate teachers. From the study, it was revealed 7 (7\%) participants suggested recommending deserving teachers for promotion, 12(12\%) suggested giving monetary incentives termly, 12 (12\%) suggested involving teachers in decision making, 2(2\%) 
suggested organizing fundraising venture, 20 (20\%) suggested offering conducive working environment, $6(6 \%)$ cited good collective budgeting, 24 (24\%) delegation of duties, 13 (13\%) awarding all teachers who meet the set target and while 4 (4\%) respondents did not give their views. Strategies for motivation were stated as; recommending deserving teachers for promotion, giving monetary incentives termly, involving teachers in decision making, organizing fundraising ventures, offering conducive working environment ,collective budgeting, delegation of duties and awarding all teachers who meet the set target.

The study found that the majority (24\%) of participants stated that delegating of duties best motivate teachers followed by providing a conducive environment that scored $20 \%$ responses. The findings of the study are similar to observations by Nwachukwu (2007) who stated that delegation permits the transfer of authority from a superior to a subordinate and empowers subordinate to make commitments. Commitment is a sign of motivation. The findings of the study are also consistent with the works of Damiana (2008) who focused on factors influencing teachers' work performance in public institutions in the central Sangwang-China.

Damiana (2008) observed that teachers tend to perform well when provided with a conducive working environment, because if properly improved to the satisfaction of a worker, one gets motivated and the output is high. The findings above are correlated with the findings from the study by Belle (2007) who concluded that teachers were proud to work in very attractive surroundings with well maintained facilities and impressive infrastructure. Organ et al. (2006) induced that transformational leaders "get followers to perform above and beyond expectation by articulating visions, providing an appropriate role model and fostering the acceptance of group goals through individualized support, intellectual stimulation and expressing high performance expectation.

Several questions were asked to respondents in a questionnaire on a number of issues. For examples, respondents were asked on whether head teachers' motivational practices have influence on teachers' job performance. From the table, $40(40 \%)$ strongly agreed, $36(36 \%)$ agreed, $0(0 \%)$ disagreed and $12(12 \%)$ strongly disagreed. From the study, majority $76 \%$ of respondents agreed that head teachers practices have influence on teacher's performance. This can be achieved through delegation. Nwachukwu (2007) emphasized that, one major principle of delegation states that, for effective delegation, authority granted to a subordinate must be equal to the responsibility assigned to him- no more no less. That is, authority delegated to an individual manager should be adequate enough to assure the ability to accomplish the expected results. A superior who refuses to delegate frustrates his subordinates as he denies them the intrinsic and extrinsic satisfaction derived from accomplishing a task. Delegation helps in training employees to assume responsibility and learn to be accountable for the assigned tasks.

Teachers were also asked to state whether some duties are delegated by school management to teachers. (20\%) of the participants strongly agreed, $44(44 \%)$ agreed, $20(20 \%)$ disagreed and $8(8 \%)$ strongly disagreed. Most (60\%) participants agreed that some duties were delegated by school management to teachers. Nwachukwu (2007) explained that delegation is an organizational process that permits the transfer of authority from a superior to a subordinate. It empowers subordinates to make commitments, use resources and take action in relation to duties assigned to him. Delegation provides means for efficient function of the organization.

Stoner, Freeman and Gilbert (2000) see delegation as the act of assigning formal authority and responsibility for completion of specific activities to a subordinate. The study established that not all teachers where involved in decision making. 12\% of respondents suggested involving teachers in school decision making. Belle (2007) agree that teachers were motivated when there was teacher centered approach to educational leadership. The issue of whether conducive working environment at school can make teachers to spend more time at school working was also asked where $46(46 \%)$ strongly agreed, $38(38 \%)$ agreed, $0(0 \%)$ disagreed and $2(2 \%)$ strongly disagreed. Most participants affirmed that a conducive working environment can make teachers spend more time at school working. This finding is consistent with the works of Damiana (2008) who focused on factors influencing teachers' work performance in public institutions in the central Sangwang-China. This study observed that teachers tend to perform well when provided with a conducive working 
environment. Belle (2007) conducted a study on the role of secondary school principals in motivating teachers in the Flacq District of Mauritius. Belle's (2007) found that teachers were proud to work in attractive surroundings with well-maintained facilities and impressive infrastructure.

Mutono, (2010) in her study which investigated factors that affected teacher motivation, showed that lack of staff accommodation, work space and distance to work places were issues that demotivated teachers. Respondents were also asked if local incentives can improve job performance where 56 (56\%) strongly disagreed, $28(28 \%)$ agreed, $0(0 \%)$ disagreed and $2(2 \%)$ strongly disagreed. The study found that local incentives can improve job performance, since most $84 \%$ of the respondents agreed. This finding is similar to Maicibi (2003) who asserted that monetary incentives are financial rewards directly related to performance. In most schools, monetary incentives are critically regarded as a motivating factor. Maicibi (2003) firmly emphasised that the motivational level depends on how each employee values it and how it's directly related to performance. The policy document, Educating Our Future (1996) recognizes that to improve teachers' commitment and motivation their terms and conditions of service must be improved.

Participants in the study were also asked to state whether capacity building for teachers can improve job performance where $40(40 \%)$ strongly agreed, $50(50 \%)$ agreed, $0(0 \%)$ disagreed and $2(2 \%)$ strongly disagreed. From the data, $90 \%$ of the respondents agree that capacity building for teachers can improve job performance. The finding of the study reinforces the existing studies that have shown that the quality of education depends on effective teaching skills, knowledge and attitudes acquired by teachers' through continuous in-service education and training and for which teachers employ at a given time leading to improved students' performance. This is in agreement with Darling-Hammond (2012) who noted that realization of student achievement gains requires teachers to have, strong content knowledge, pedagogical knowledge and skills of how to teach others; understanding learners and their development, having general abilities for organizing, observing, explaining ideas, thinking diagnostically and having adaptive expertise for making judgment in light of student needs in a given context6\% of participants suggested collective budgeting as way of motivating teachers for good performance

The study also revealed challenges faced by head teachers in providing motivation to the teachers in public secondary schools. The study found that $16(16 \%)$ of participants cited not enough funding from government, $12(12 \%)$ stated that most learners do not pay tuition fees, $12(12 \%)$ bemoaned low staffing levels in some subjects, 34 (34\%) complained of too much interference from the higher offices, $16(16 \%)$ noted that head teachers have less control on teacher transfers and recruitment, 18 (18\%) complained of lack of conducive working environment while $6(6 \%)$ of the respondents did not provide any answer.

Head teacher B indicated that collecting school fees from the parents was a challenge as the government issued a statement that no learner should be chased from school for none payment of school fees. So the school had no finances to purchase the required materials.

Head teacher D suggested that the major challenge was the non-availability of resources and that teachers only want to be motivated in monetary form.

Majority of the participants $34 \%$ complained of too much interference from the higher offices. Nwachukwu (2007) emphasized that, one major principle of delegation states that, for effective delegation, authority granted to a subordinate must be equal to the responsibility assigned to him- no more no less.

\section{CONCLUSIONS AND IMPLICATIONS}

The study concluded that head teachers play a vital role in motivating teachers and that these motivation practices had a positive impact on teachers' performance. Further that apart from the motivational incentives given by the Ministry of Education, head teachers should enhance their motivational practices by concentrating on local incentives such as delegation of duties, capacity building and recognition of hard work. 


\section{RECOMMENDATIONS}

Based on the findings, the study recommends stronger and timely motivation practices by head teachers in order to enhance teacher performance. These practices may not necessarily be in monetary terms but such as writing commendation letter to teachers who perform well and general appreciation of good performance by teachers.

\section{AREAS FOR FURTHER RESEARCH}

The study recommends a similar study to be done in rural secondary school because this one was done in urban areas.

\section{REFERENCES}

[1] Aikman S. and Interhalter, E. (2005) 'Beyond Access' transforming policy and practice for gender Equality in Education. London: Charles E. Merrill Publishing Co.

[2] Akyeampong K. (2007) Teacher Motivation in Sub Saharan Africa and South East Asia. London: Pearson.

[3] Armstrong M. (2003). A hand book of human resource management practice. London: Cambrian Printers ltd.

[4] Armstrong S. (2006). A hand book of Management and Leadership: A guide to Management for results. London: Kogan..

[5] Bass B. M., \& Riggio, R. E. (2006). Transformational leadership (2nd ed.). Mahwah, NJ: Lawrence Erlbaum Associates.

[6] Bauleni A (2005) The Fundamental Principles of Modern School Management and Institutions of Higher learning. Lusaka: Zambia Educational Publishing House.

[7] Belle H. J. (2007). The Role of Secondary School Principals in Motivating Teachers in the Flacq Distinct of Mauritius. MA Dissertation, University of South Africa.

[8] Blase, J and Blase J.R. (1994). Employing Teacher: What Successful Principals Do, Thousand Oak: Corium Press Ink.

[9] Cappelli N. D. (2001). Do High-Performance Work Practices Improve Establishment-Level Out-Comes? Industrial and Labor Relations Review.

[10] Cuban L. (1984) Transforming the frog into a prince: effective schools research, policy, and practice at the district level. Harvard Educational Review, 54(2), pp. 129-151.

[11] Davidson, E. (2004). The Pivotal Role of Teachers Motivation in Tanzania Working Paper Na.7, Dar es Salaam: Hakielimu.

[12] Darling- Hammond, L. (2012), Creating a Comprehensive System for Evaluating and Supporting Effective Teaching, Stanford CA

[13] Darmiana, T. (2008). Critical Success Factors for Organizational Growth, the Human Resource Management Approach to Institutional Development.

[14] Dessler G. (2003). Human Resource Management, London: Prentice Hall.

[15] Emenike O. (2010). Influence of Monetary Rewards on Employee Productivity in Private, Organizations In Nigerians Rural Private Firms.

[16] Frase, L.E (1992). Teacher Motivation and Satisfaction: Impact on Participatory Management, NASSP Bulletin

[17] Gilbert,D.R, et al (2000), Management, Pearson Education

[18] Herzberg, F. (1959). Work and the Nature of Man, New York, the World Publishing Co.

[19] Johari, M. (2014).The Role of School Leadership in Motivating Teachers. M.A. Dissertation. Open University of Tanzania.

[20] Johnson, S. M. (1986). Incentives for Teachers: What Motivates, What Matters,Education Quarterly, Vol 22(3):54-79

[21] Leithwood. K.(1994) Leadership for school restructuring, Educational Administration Quarterly, 30(4), pp. 498-518.

[22] Maicibi N. A. and Nkata, J. L. (2005). Introduction to human resource management, Kampala: Masah Publications.

[23] Ministry of Education (1996). National Policy on Education; Educating our Future. Lusaka: Zambia National Publishing House.

[24] Mutono V. (2010). Factors Affecting Teacher Motivation in Zambia: the case of selected high schools of Lusaka Province. Unpublished Masters Thesis. University of Zambia. 
[25] Nairuba Justine (2011) Motivational Practices and Teachers ${ }^{\text {ee }}$ Performance in Jinja Municipality Secondary Schools, JINJA DISTRICT, UGANDA

[26] Nwachukwu C. C. (2007). Management Theory and Practice, Onitsha: African First Publishers Limited.

[27] Organ D. W., Podsakoff, Ph. M., \& MacKenzie, S. B. (2006). Organizational Citizenship

[28] Pamela H. (2005). Motivation Factors Influence Teacher's Engagement in Post Graduate Student: The Results of a Study of Five Schools a paper presented at Australian association of research in education conference.

[29] Robbins R. (2001). Determinants of Job Satisfaction of Municipal Government Employees (Electronic version).Public Personnel Management, 31(3), 343-358.

[30] Situmbeko M. N (2016) To what extent do head teachers motivate teachers to teach effectively: A Case of selected secondary schools in Ndola urban District Zambia.

[31] Vroom V. H. (1964). Work and Motivation. New York: Wiley press.

\section{AUTHORS' BIOGRAPHY}

Mawala Muluka Mukumbi is a secondary school teacher who holds a Diploma in Business Studies, Bachelors' degree in Business Studies with Education and has recently completed her Master of Arts Degree in Education Administration and Leadership at Mulungushi University. She has 13 years secondary school teaching experience and was appointed as H.O.D Business Studies in 2018.

Rachel Mabuku Kabeta holds a $\mathrm{PhD}$ (Education Administration), has 29 years teaching experience in secondary school, teacher training at college and university level. She specializes in teaching and research in Education Management, Administration and Leadership. She is currently a lecturer at Mulungushi University in the School of Education.

Citation: Mawala Muluka Mukumbi, Rachel Mabuku Kabeta. "Influence of Head Teachers' Motivational Practices on Teacher Performance in Public Secondary Schools of Chililabombwe District- Zambia". International Journal of Humanities Social Sciences and Education (IJHSSE), vol. 6, no.9, 2019, pp. 117-125. doi: http://dx. doi.org/10.20431/2349-0381.0609013.

Copyright: () 2019 Authors. This is an open-access article distributed under the terms of the Creative Commons Attribution License, which permits unrestricted use, distribution, and reproduction in any medium, provided the original author and source are credited. 